\title{
Development of Napier's Bones Equipment for Improving Student Learning Outcomes in Multiplication Counting Operations at Grade III SDN 13 Sitiung Dharmasraya Regency
}

\author{
$1^{\text {st }}$ Ratnawati \\ Department of Mathematics \\ Universitas Dharmas Indonesia \\ Dharmasraya, Indonesia \\ mbakratna84@gmail.com
}

\author{
$2^{\text {nd }}$ Piki Aprizal \\ PGSD \\ Universitas Dharmas Indonesia \\ Muaro Bungo, Jambi \\ vikiaprizal02@gmail.com
}

\author{
$3^{\text {rd }}$ Kelik Purwanto \\ Department of Economics \\ Universitas Dharmas Indonesia \\ Dharmasraya, Indonesia \\ klkpurwanto@gmail.com
}

\begin{abstract}
The development of grade 3 Elementary School (SD) students are including the concrete operational, to understand the concept of mathematics students need props. One of them is the Napier's Bones (Tulang Napier). The purpose of this research is to develop the props. Napier's Bones is multiplication to improve the results of the students mathematic in learning prosess for Grade 3 in SD 13 sitiung. This development are consists of 4 stages or 4D; Define, Design, Develop and Desseminate. Although this research is limited discuss until to develop. Development of props in Napier's Bones on multiplication counts in material of Grade 3 SD through curriculum analysis, student analysis, and material analysis. Validation is done by the expert, the purpose of the validation is to see the best concepts, forms and appearance as well as good in language form. Practicality is obtained from questionnaires for teachers and students. The results are declared with percentage value of $77.38 \%$ (valid), $86.40 \%$ (very practical), and $\mathbf{7 1 . 4 2 \%}$ (effective). Development Napier's Boness is operation counting student multiplication in grade 3 SDN 13 sitiung district Dharmasraya can be used.
\end{abstract}

Keywords-Napier's Bonesss, Learning Student Outcomes, Multiplication Counting Operations

\section{INTRODUCTION}

Education is a right for every citizen. Education has been regarded as a freely human right which available to all citizens. Education is a conscious and well-planned effort to create an atmosphere of learning process so that students actively develop their potential to have spiritual power, selfcontrol, personality, intelligence, good character, and skills needed for society, nation and state [15]. Education is a must for humans because with human education will have the ability and personality that developed. Education begins from human birth until the human being close the age or often referred to as long life education. Education is a process of growth and development, as a result of individual interaction with the social environment and physical environment, lasting throughout life since human birth [8].

Based on the above opinion can be concluded that education is a deliberate act to make people have a better quality, from not knowing to know, from not understand to understand, and so forth.
The process of education can not be separated from a learning, in which learning itself is essentially a process of interaction either directly or indirectly between teachers with students, students with teachers or between students and students. Directly through face-to-face and indirectly using various media.

Learning is anything that is designed like methods, models, and media to facilitate students in learning. Learning is all efforts made by teachers (educators) to happen the learning process in students [14]. Implicitly, in learning there are activities of choosing, establishing and developing methods to achieve desired results. Learning emphasizes how to organize the subject matter, deliver the subject matter and manage the lesson.

Children, especially elementary school age (7-11 years), based on Jean Piaget, are at a concrete operational stage. So, naturally the best way to learn them is to actually see, feel and do with their hands. The concept as far as possible is taught by being seen, held, and enhanced, drawn, spoken, and written [4]. This real-life experience will greatly assist the child in shaping the abstractions needed to understand mathematics. Then the three stages in the development of the students is the sensorimotor stage (0-2 years), at this stage is the ability of the child visible from the motor activities and simple perception. The next stage is the preoperational stage (2-7 years), in this stage the child has been able to use the language in developing the concept, although it is still very simple. Lastly, the formal operational stage (12-18 years), in this stage the child is able to think abstractly and logically.

One of the compulsory subjects that can help students develop their potential to have intelligence, good character, and skill is mathematics. Mathematics as a science has characteristics, namely (1) having abstract objects, (2) resting on agreement, (3) deductive mindset, (4) having empty symbols of meaning, (5) paying attention to the universe of speech, and (6) consistent in the system [10]. In mathematics every abstract concept newly understood students need to be reinforced in order to survive in students' memory, so it will be embedded in the mindset and pattern of action [5]. Error in mathematical concepts can be caused by teachers and students. Factors from teachers include the teacher does not master the appropriate approaches and learning methods in delivering the material. Mastery of the material must also be 
owned by every teacher. If the teacher does not master the concept, it is likely to convey the wrong concept which is accepted by the student. Based on the observations at SDN 13 Sitiung, it shows that the 3rd graders at SDN 13 Sitiung have difficulties in studying multiplication counting, this is because the mathematics learning which has characteristic is abstract, and the 3rd grade students are still at the operational concrete stage, then the students need props that can deliver students in understanding the concept of mathematics so that students can be excited and motivated in learning multiplication counting operations. It will make student's learning outcomes increase.

The visual aids are anything that can be used to send messages and can stimulate students' thoughts, feelings, concerns, and willingness to encourage student's learning. Props are teaching aids that are used for teaching in order to make learning run well and in line with the goals [11]. The meaning of props is to help students easily understand the lesson, master the contents or increase the dexterity of the lesson concerned [3].

Based on description above, the authors can conclude that props are an important part of learning. The props clarify the delivery of materials as intermediaries in learning, so that students can understand the material well and can be motivated in learning.

One of the mathematical props developing today is the Napier's Bones. Napier's Bones make it easy for students to multiply counting operations. Napier's Bones discovered by John Napier was a Scottish mathematician and was widely used in the 1600s. Napier's Bones props (Napier's Bones) known as Napier's Bones is a rod-shaped mathematical tool containing a number of indices and numbers, used to determine the multiplication of a number [9]. The idea of thinking is to transform complex processes of multiplication and division into additions and subtractions. The Napier's Bones media is designed to simplify the difficulty in multiplication by converting multiplication into summation with the Lattice Method concept (lattice method) [13]. Meanwhile, Napier buffer tool is made of wooden slab or bone with a small size so that it can be inserted into the pocket [9]. In addition, this Napier's Bones can be moved easily so that students can be more enthusiastic to actively participate physically by moving the number objects. The pattern of teaching can make students easier to multiply it because it is arranged in a square box, making it easier for children to multiply the numbers with one another. By using Napier's Bones props, student's learning outcomes in learning multiplication counting operations increased.

Learning outcomes are benchmarks used to determine the level of students' success in knowing and understanding a subject, usually expressed by the value of a letter or numbers. Learning outcomes can be in form of skills, values and attitudes after students experience the learning process. Learning outcomes is the ability obtained by children through learning activities [1]. Learning itself is a process of a person, in which learning outcomes are influenced by intelligence and control of the child about the material he or she will learn. The results of learning is the result of an interaction of learning and teaching acts and usually indicated by the value of tests given teachers [6]. Based on the explanation above, the results of learning is the success or mastery of a student to the field of study after taking the teaching and learning process that it can be looked at the good value in the form of numbers, letters, attitudes and values of skills.

\section{METHODS}

This research is a developmental research which developed props. The development of these props uses $4 \mathrm{D}$ model (four D) consisting of four (4) stages: define, design, development and disseminate. Research development is done until the development stage (develop). The steps of drafting development Napier's Bones props can be detailed as follows:

\section{A. Definition Stage (Define):}

The stages are Curriculum analysis, student analysis, and material analysis.

\section{B. Design Stage:}

1. Preparation of Research Instrument consisting of validation sheet, questionnaire and test of learning result. In this section of validation there are three important components: validation of constructs, content validation and language validation.

2. Designing of the props development tool is done by preparing the necessary tools. Tools and materials for making Napier's Bones props on multiplication counting material are as follows:

a. 10 Pieces of wood and several pieces of wood used for the frame.

b. 2 pieces of cardboard.

c. 1 bottle of paper glue.

d. 1 piece of wood called index, divided into 10 boxes for the numbers 0-9.

e. 9 pieces of wood divided into 10 boxes are also then filled with numbers to be multiplied.

\section{Development Stage:}

Test Validity, Practicality Test, and Effectiveness Test.In this research the product produced in the form of Napier's Boness props on the material of multiplication count operation in third grade SD N 13 Sitiung Dharmasraya Regency.

This research was conducted at SD Negeri 13 Sitiung in the third grade which amounted to 28 students that consist of 16 female students and 12 male students.

There are two kinds of data taken in this research that are quantitative and qualitative data. Quantitative data obtained from the effectiveness data taken from student learning outcomes by using Napier's Bones props. While the qualitative data taken from the validation conducted by the validator and practical data taken from the observation of props Napier's Bones.

Validation data analysis is done by using Likert scale. Practical data analysis is done by finding the percentage of practicality. Analysis of effectiveness data is done by finding the value of each student learning. 


\section{RESUlT OF DEVELOPMENT}

The results of Napier's Bones props design on multiplication counting material can be seen in figure 1 .

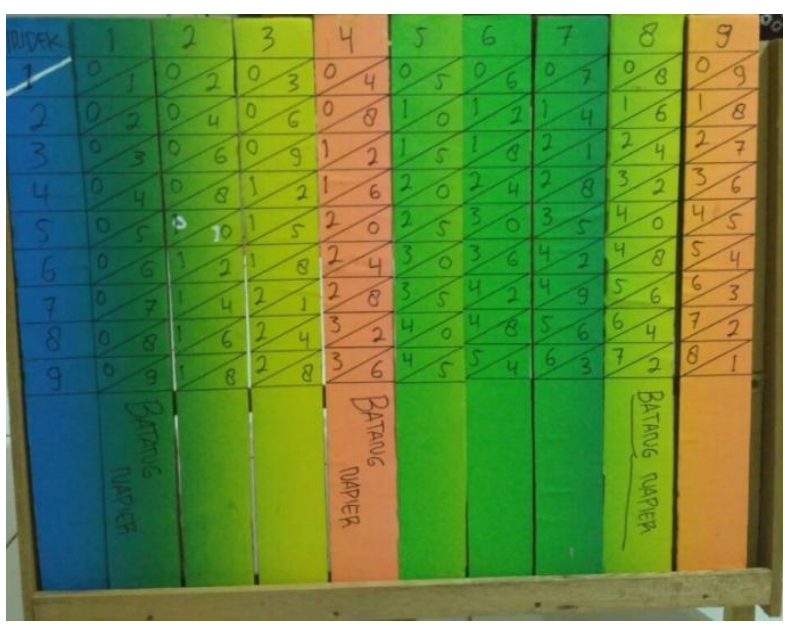

Fig. 1. Napier's Boness Tool

Based on picture 1 the image of the Napier bar tool consists of index (1-9) and the number to be multiplied (1-9).

\section{A. Validity Test Results}

TABLE I. NAPIER'S BONES VALIDATION RESULTS

\begin{tabular}{|c|c|c|}
\hline Validator & Result (\%) & Category \\
\hline I & 80 & Valid \\
\hline II & 77.14 & Valid \\
\hline III & 75 & Valid \\
\hline Average & 77.38 & Valid \\
\hline
\end{tabular}

Based on the assessment of the 3 validators in Table 1 above the Napier bar tool has an average percentage rating of $77.38 \%$. In accordance with the modified validation validation category of the Riduwan (2015: 89) then the percentage of scoring is within the $60-80 \%$ range falling within the valid category.

\section{B. Practicality Test Results}

TABLE II. PRACTICALITY TEST RESUlts

\begin{tabular}{|c|c|c|c|}
\hline No & Practitioner & Results (\%) & Category \\
\hline 1 & Teacher & $82 \%$ & Very Practical \\
\hline 2 & Students & $90.92 \%$ & Very Practical \\
\hline \multicolumn{2}{|c|}{ Average } & $86.46 \%$ & Very Practical \\
\hline
\end{tabular}

Based on the results of the assessment of teachers and students above, the Napier's Bones props has an average assessment of teachers and students is $90.92 \%$ with very practical criteria.

\section{DISCUSSION}

\section{A. Validity of Napier's Boness Tool}

Based on the results of the assessment of the 3 validators in table 1 props rod Napier have $77.38 \%$ percentage assessment. In accordance with the modified validation category of the Riduwan [7] then the percentage of scoring is within $60-80 \%$ range falling within the valid category. Who states that an instrument is said to be valid if the instrument can be used to measure what should be measured [12]. Validity tests performed include content validity, constructs, and language validity. Based on the results Napier's Bones props are developed in accordance with the material presented and available with the level of student development.

\section{B. Practicality of Napier's Boness}

The results of the analysis from the questionnaires filled by teachers showed that the teacher's response to the Napier's Bones props was $86.46 \%$. The percentage of these assessments by Riduwan [7] is included in the very practical category. In addition, the results of the responses from the questionnaire of the students' responses are at $82 \%$ percentage which is at very practical criteria. The average assessment of teachers and students is $90.92 \%$ with very practical criteria, so this indicates that the Napier's Bones props on multiplication counting material is very practical to use in the learning process. Practically refers to the extent that the user (or other experts) consider the intervention as appealing and usable in normal conditions [2].

\section{Effectiveness of Napier's Boness}

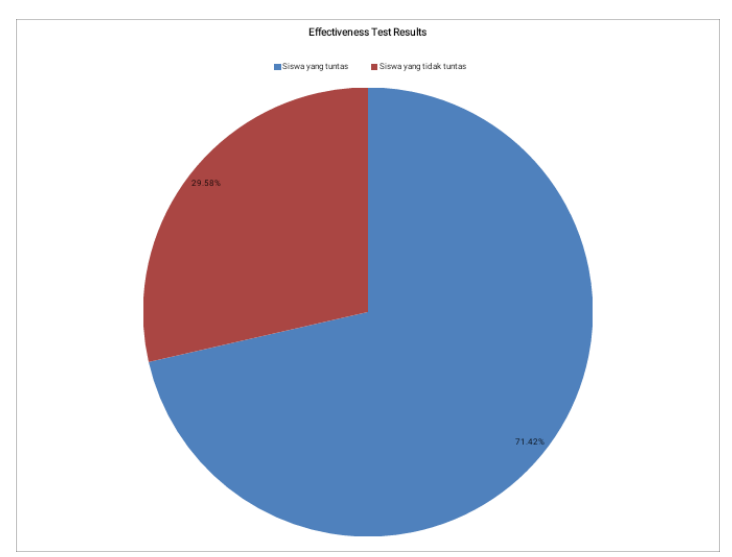

Based on the results of the test students showed $71.42 \%$ of students complete in learning. This percentage according to Riduwan (2015: 89) included into the effective category. So this indicates that the Napier's Bones props on multiplication counting materials are effectively used in the learning process. According to Akker (1999) there are two aspects of effectiveness that must be met by a teaching material, Akker provides the following parameters:

a. Experts and practitioners based on experience stated that the teaching materials are effective.

b. Operationally the teaching materials deliver results as expected. 


\section{CONCLUSION}

Based on the development that has been done to Napier's Boness props on multiplication counting operation got the following conclusion:

a. Validity Napier's Bones props on the matter of counting operation of the students of grade III SD obtained $77.38 \%$ percentage of the valid category, meaning in accordance with the material presented and in accordance with the level of student development.

b. Practicality assessed from the results of questionnaires teachers and questionnaire responses of students by studentss show that props stem Napieron the matter of counting operations of grade III SD students get percentage $86.46 \%$ is in the category very practical. It means that the props can be applied by the teacher in accordance with the planned and easy to use by students, the time used is right and not too long.

c. The effectiveness assessed from the students's test result on the Napier's Bones props on the material of third grade SD multiply counting operation obtains the percentage of $71.42 \%$,it is in the effective category. So this indicates that props rod Napier on multiplication counting material is effectively used in the learning process in helping students achieve learning objectives.

\section{REFERENCES}

[1] Abdurrahman. M., Education for Children in Learning Difficulties, Jakarta: RinekaCipta, 1999.

[2] Akker, "Validity, Practicality and potential effect of a teaching material", (Online), (http: //12/kevalidan-kepraktisan- and-efek.html, accessed April 11, 2017).

[3] Crow and Crow, Introduction to Educational Science, Yogyakarta: Rake Sarasin, 1990.

[4] Fatimah, Mathematics Fun with Modeling Methods, Bandung: Tarsito, 2009.

[5] Heruman, Memory Learning Models in Primary School, Bandung: PT RemajaRosdakarya, 2010.

[6] Nasution, Various Approaches inTeaching and Learning Process, Jakarta: PT BumiAksara, 2006.

[7] Riduwan, Statistics Basics, Bandung: Alfabeta, 2015.

[8] Sadulloh. Uyoh. Drs., Et al., Pedagogic (Educational Science), Bandung: Alfebata, 2010.

[9] Sobel. M.A and Maletsky E.M., Teaching Math, Jakarta: Erland, 2004.

[10] Soedjadi. R., Tips on mathematics education in Indonesia: Conflicting the present situation towards future expectations, Directorate General of Higher Education, 325, 2000.

[11] Sriyono, Teaching and Learning Techniques in CBSA, Jakarta: RinekaCipta, 1992.

[12] Sudijono. Anas, Introduction to Educational Evaluation, Jakarta: Rajawali Pers, 2009

[13] Supriyadi. D., Secrets of Quick and Easy Counting of Napier Trunk Methods, Bandung: Prestige Publishing, 2011.

[14] Sutikno. Sobry, Learning and Learning. Bandung: Prospect, 2007.

[15] Law of the Republic of Indonesia Number 20 Year 2003 on National Education System. 